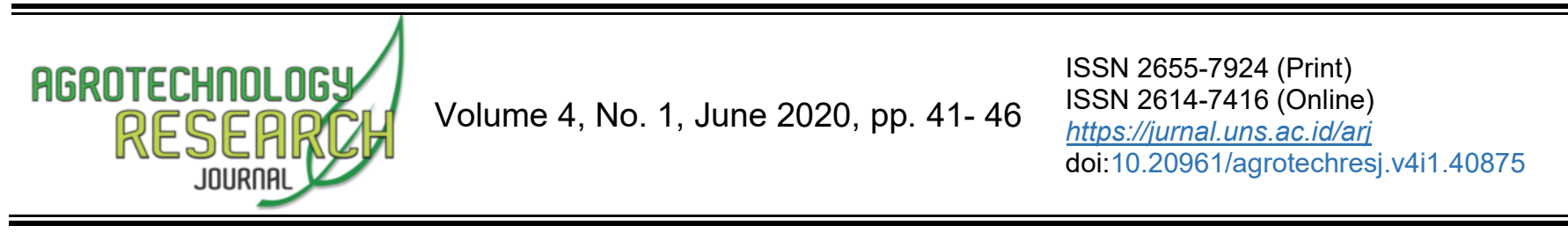

\title{
Identifikasi Plant Growth Promoting Rhizobacteria pada Rizosfer Bambu Duri dengan Gram KOH 3\%
}

\author{
Muhammad Yusril Hardiansyah ${ }^{1 *}$, Yunus Musa ${ }^{2}$, Abdul Mollah Jaya ${ }^{3}$ \\ ${ }^{1-3}$ Agrotechnology Study Program, Department of Agronomy, Faculty of Agriculture, Universitas Hasanuddin, Makassar, Indonesia
}

Received 24 March 2020; Accepted 23 May 2020; Published 25 June 2020

\begin{abstract}
Plant Growth Promoting Rhizobacteria is a group of microorganism that is able to increase plant growth and yield through reactions in the soil, but the large number of microorganisms contained in PGPR's rhizosphere from thorn bamboo make it difficult to know which bacteria are the most dominant and most active in influencing plants. This study aimed to determine the effect of using the $3 \%$ gram KOH test method in identifying PGPR bacteria from the thorn bamboo rhizosphere. This test was carried out at the Biofertilizer and Potential Microbial Laboratory, Faculty of Agriculture, Universitas Hasanuddin from October-December 2019. The testing methods include making microorganism growing media, pouring media, planting bacteria with the scatter and scratch methods, also the gram reaction test using $\mathrm{KOH} 3 \%$. The results obtained the use of the $3 \%$ gram $\mathrm{KOH}$ test method in the scatter method showed there were 2 samples that have mucus with a percentage of $40 \%$, while in the scratch method showed all samples have mucus with a percentage of $100 \%$ so that the use of the $3 \%$ gram $\mathrm{KOH}$ test method has an optimum effect in detecting microorganisms especially in identifying plant growth promoting rhizobacteria.
\end{abstract}

Keywords: Microorganism; Scatter; Scratch

Cite This As (CSE Style): Hardiansyah MY, Yunus M, Jaya MA. 2020. Identifikasi Plant Growth Promoting Rhizobacteria pada Rizosfer Bambu Duri dengan Gram KOH 3\%. Agrotech Res J 4(1): 1-5. https://doi.org/10.20961/agrotechresj.v4i1.40875

\section{PENDAHULUAN}

Plant Growth Promoting Rhizobacteria (PGPR) merupakan kelompok mikroorganisme tanah yang hidup di rizosfer tanaman dan merangsang pertumbuhan serta perkembangan tanaman inang. PGPR merupakan mikrobiota tanah yang paling penting dan bermanfaat secara agronomis (Lugtenberg dan Kamilova, 2009; Bhattacharyya dan Jha, 2012). Akar tanaman yang berkembang dengan baik akan efisien menyerap unsur hara sehingga tanaman tidak mudah terserang patogen. Selain itu, peningkatan pertumbuhan tanaman oleh PGPR dapat terjadi melalui satu atau lebih mekanisme yang terkait dengan karakter fungsional PGPR dan kondisi di lingkungan rizosfer (Rahni, 2012). PGPR ialah mikroorganisme hayati yang mampu meningkatkan pertumbuhan dan hasil tanaman. Bakteri yang terkandung dalam PGPR dapat diklasifikasikan berdasarkan pengaruhnya terhadap tanaman dan cara berinteraksi dengan akar, PGPR dapat mempengaruhi tanaman secara langsung dan tidak langsung (Saharan dan Nehra, 2011). PGPR sangat penting dan telah banyak dipelajari sebagai pupuk hayati untuk

\section{${ }^{*}$ Corresponding Authors:}

${ }^{1}$ E-Mail: yusrilhardiansyah1@gmail.com meningkatkan pertumbuhan dan hasil tanaman. Efek spesifik PGPR dihasilkan dari beberapa mekanisme termasuk produksi senyawa volatil (Zhang et al., 2007), peningkatan ketersediaan mineral dan nitrogen dalam tanah (Lin et al., 1983), dan produksi regulator pertumbuhan tanaman yakni asam indol asetat (AIA), giberelin dan sitokinin yang secara langsung meningkatkan pertumbuhan tanaman dengan meningkatkan luas permukaan akar dan jumlah rambut akar (Bottini et al., 2004; Khalid et al., 2004; Liu et al., 2017; Ryu et al., 2005; Tsavkelova et al., 2006).

Bambu merupakan tanaman yang dapat tumbuh di beberapa daerah di Indonesia dengan keragaman fungsi dan spesies. Di Indonesia terdapat 60 spesies bambu dari 200 spesies yang ada di kawasan Asia Tenggara dan dapat dijumpai di daerah yang bebas dari genangan air, mulai dari dataran rendah hingga pegunungan. Sifat adaptasi bambu yang tergolong tinggi membuat tanaman ini dapat tumbuh baik hampir di setiap jenis tanah (Widjaja et al. 1995). Hingga saat ini telah banyak dilaporkan mikroba antagonis potensial asal rizosfer bambu yang memiliki daya antagonisme terhadap patogen tular tanah (soil borne disease) melalui mekanisme antagonis berupa persaingan hidup, parasitisme, antibiosis dan induced systemic resistance (Zahir et al. 2004). PGPR berperan penting dalam pertumbuhan dan metabolisme tanaman. Aktivitas 
mikroorganisme tanah dipengaruhi oleh berbagai faktor lingkungan dan faktor terkait tanaman (spesies dan umur). Dalam dua dekade terakhir ini, berbagai jenis PGPR telah diketahui memainkan peran penting dalam meningkatkan pertumbuhan tanaman. Varietas tertentu dari strain PGPR milik Bacillus, Enterobacter, Burkholderia, Acinetobacter, Alcaligenes, Arthrobacter, Azospirillium, Azotobacter, Beijerinckia, Erwinia, Flavobacterium, Rhizobium, dan Serratia sekarang digunakan di seluruh dunia dengan tujuan untuk meningkatkan produktivitas tanaman (Burd et al., 2000; Chaiharn et al., 2008; Yang et al., 2009; Bharti et al., 2013).

Penelitian terhadap keberadaan dan keragaman mikroba rizosfer bambu telah dilakukan oleh beberapa peneliti sebelumnya. Menurut Sharma et al. (2010) pada rizosfer tanaman bambu sehat ditemukan cendawan antagonis seperti Aspergillus, Penicillium, dll. yang mampu menekan patogen Fusarium dan Phytophthora. Penelitian yang dilakukan oleh Asniah et al. (2013) menunjukkan bahwa inokulasi fungi Paecilomyces $\mathrm{sp}$ dan Chaetomium globosum asal rizosfer bambu ke dalam tanah persemaian berpengaruh nyata terhadap penurunan indeks penyakit akar gada dan peningkatan bobot basah tanaman brokoli. Penelitian yang dilakukan Tu et al. (2013) di Cina terhadap rizosfer 6 spesies bambu menunjukkan bahwa total populasi cendawan dan bakteri serta aktivitas mikrob pada tanah rizosfer bambu sangat tinggi dan berpengaruh positif terhadap pertumbuhan tanaman.

Bambu duri (Bambusa blumeana) memiliki potensi yang besar yakni mempunyai sistem perakaran serabut dengan akar rimpang yang sangat kuat yang dapat menjaga sistem hidrologis sebagai pengikat tanah dan air serta akar yang mampu mencegah erosi dan dapat menyerap air hingga $90 \%$ selain itu bambu duri juga berupa rumpun yang dapat menciptakan iklim mikro di sekitarnya (Sutrisno, 2008). Kondisi kelembaban mikro yang terdapat pada jenis bambu ini mengakibatkan luasnya cakupan mikroorganisme yang hidup dan berada di rizosfer bambu duri sehingga menyebabkan tanah di sekitar perakaran bambu tersebut cukup subur.

Kajian terhadap keragaman mikroorganisme hidup pada PGPR sering kali dilakukan oleh para peneliti dalam melakukan seleksi terhadap berbagai jenis bakteri, namun banyaknya mikroorganisme yang terkandung dalam PGPR rizosfer bambu duri mengakibatkan sulitnya untuk mengetahui jenis bakteri yang paling dominan dan aktif dalam mempengaruhi pertumbuhan tanaman. Oleh karena itu metode yang dapat dilakukan untuk mengetahui jenis bakteri yang terkandung yakni melakukan identifikasi mikroorganisme dengan perlakuan uji biokimia. Menurut Rahayu dan Gumilar (2017), uji biokimia bakteri merupakan suatu cara atau perlakuan yang dilakukan untuk mengidentifikasi dan mendeterminasi suatu biakan murni bakteri hasil isolasi melalui sifat-sifat fisiologinya. Proses biokimia erat kaitannya dengan metabolisme sel, yakni selama reaksi kimiawi yang dilakukan oleh sel yang menghasilkan energi maupun yang menggunakan energi untuk sintesis komponen-komponen sel dan untuk kegiatan seluler, seperti pergerakan. Salah satu metode yang digunakan dalam mengidentifikasi mikroorganisme yakni uji gram dengan $\mathrm{KOH} 3 \%$.

Metode gram dengan pengujian $\mathrm{KOH} 3 \%$ merupakan metode identifikasi bakteri yang baik dalam menentukan jenis dominan bakteri yang aktif yang ditandai dengan adanya lendir. Apabila bakteri yang dicampurkan terlalu sedikit akan menimbulkan kesalahan dalam pengujian dan memungkinkan tidak bereaksi, sehingga dalam pengujian ini penggunaan latar berwarna gelap sangat baik. Penentuan sifat gram dengan $\mathrm{KOH} 3 \%$ memiliki hasil yang sama dengan pengujian pewarnaan gram. Pengujian $\mathrm{KOH} 3 \%$ pada bakteri mengindikasikan bakteri gram $(+)$ memiliki dinding sel yang tebal dan lemak yang tipis sedangkan gram (-) berlemak tebal dan berdinding sel tipis yang berada di ruang periplasma. $\mathrm{KOH}$ akan menyerang lemak (bilayer lipid) dan membuat sel gram (-) pecah. Sel yang pecah akan melepaskan materi genetik (DNA) yang merupakan substansi melimpah di dalam sel bakteri. Molekul DNA sangat panjang bersifat sticky strings (menyerupai lendir, getah atau dapat berarti lengket) yang memberikan hasil seperti lendir saat diangkat dengan jarum inokulum (Edwin, 2011).

Penelitian ini bertujuan untuk mengetahui pengaruh dan manfaat terhadap penggunaan metode uji gram $\mathrm{KOH} 3 \%$ dalam mengidentifikasi bakteri Plant Growth Promoting Rhizobacteria dari rizosfer bambu duri. Informasi dari hasil penelitian ini diharapkan dapat menjadi solusi bagi para peneliti atau akademisi dalam melakukan tahapan proses identifikasi terhadap berbagai mikroorganisme.

\section{BAHAN DAN METODE}

Penelitian ini dilaksanakan di Laboratorium Biofertilizer dan Mikroba Potensial, Departemen Budidaya Pertanian, Fakultas Pertanian, Universitas Hasanuddin, Makassar. Pengujian berlangsung pada Oktober-Desember 2019. Alat yang digunakan adalah laminar air flow, neraca analitik, mortar, tabung reaksi, rak tabung, cawan petri, gelas ukur, erlenmeyer, jarum ose, pipet tetes, pipet mikro, spatula, autoclave, oven, hotplate, vortex dan kaca preparat. Bahan yang digunakan adalah larutan Plant Growth Promoting Rhizobacteria dari rizosfer bambu duri (Bambusa blumeana), $\mathrm{KOH} 3 \%$, alkohol $70 \%$, alkohol $96 \%$, air, Aquades, deg glass, nutrient broth (NB), agar, Bunsen, plastik wrap dan aluminium foil.

Langkah-langkah pelaksanaan pengujian sebagai berikut :

\section{Pembuatan media tumbuh mikroorganisme}

Pembuatan media tumbuh mikroorganisme dengan menggunakan media Nutrient Agar (NA). Pembuatan NA dilakukan dengan menggunakan $8 \mathrm{gram}$ nutrient broth dan 20 gram agar kemudian dilakukan sterilisasi basah menggunakan autoclave. 


\section{Penuangan media}

Penuangan media NA di atas cawan petri sekitar 15-20 $\mathrm{ml}$, kemudian ditutup dan direkatkan dengan plastik wrap lalu. Media di simpan pada kotak penyimpanan dan didiamkan hingga media memadat.

\section{Penanaman mikroorganisme}

Penanaman mikroorganisme dilakukan dengan dua metode yaitu metode sebar dan metode penggoresan. Setiap metode dibuat dalam masing-masing 5 cawan petri. Bahan berupa larutan PGPR rizosfer bambu yang telah dibuat sebelumnya kemudian dilakukan penuangan ke media NA. Pelaksanaan metode sebar dilakukan dengan mengambil larutan PGPR sebanyak 1 $\mathrm{ml}$ menggunakan pipet mikro kemudian di sebar di atas media NA dan diratakan menggunakan spatula, sedangkan untuk metode penggoresan dilakukan dengan mengambil jarum ose kemudian dilakukan sterilisasi pemijaran pada bunsen kemudian dicelupkan pada larutan PGPR dan dilakukan penggoresan secara zig-zag di atas permukaan media NA dalam cawan petri. Setelah penanaman bakteri dilakukan, cawan tersebut disimpan di dalam kotak penyimpanan serta dilakukan pengecekan dan pengamatan fisik pertumbuhan bakteri setiap harinya.
4. Uji reaksi gram menggunakan $\mathrm{KOH} 3 \%$

Pengujian dengan $\mathrm{KOH} 3 \%$ hanya bertujuan mengetahui jenis Gram. Metode pengujian dengan $\mathrm{KOH} 3 \%$ yaitu melalui pencampuran isolat bakteri dengan $\mathrm{KOH} 3 \%$ pada kaca preparat steril. Metode identifikasi bakteri dilakukan dengan menaruh 1 tetes $\mathrm{KOH} 3 \%$ di atas kaca preparat kemudian bakteri yang telah tumbuh dari metode sebar dan metode penggoresan diambil dengan jarum ose dan digosokkan pada larutan $\mathrm{KOH} 3 \%$ dan dilakukan pengamatan. Satu lingkaran koloni bakteri dari lempeng kultur diemulsi di atas kaca slide dalam suspensi $3 \% \mathrm{KOH}$. Suspensi diaduk terus menerus selama satu menit dan kemudian loop ditarik dengan lembut. Tes dianggap positif jika string terlihat dalam 30 detik pertama setelah pencampuran dalam larutan $\mathrm{KOH}$ (Jaya et al., 2011), Parameter pengamatan berdasarkan kategori jenis gram mikroorganisme dimana kategori bakteri gram negatif diperoleh apabila menghasilkan lendir (reaksi positif) dan kategori bakteri gram positif apabila tidak menghasilkan lendir (reaksi negatif).

\section{HASIL DAN PEMBAHASAN}

Hasil pengujian reaksi gram mikroorganisme plant growth promoting rhizobacteria dari rizosfer bambu duri menggunakan $\mathrm{KOH} 3 \%$ dapat dilihat pada Tabel 1 .

Tabel 1. Uji reaksi gram menggunakan $\mathrm{KOH} 3 \%$ pada Plant Growth Promoting Rhizobacteria dari rizosfer bambu duri dengan metode sebar dan metode gores

\begin{tabular}{lccccc}
\hline Metode/Jenis & \multicolumn{5}{c}{ Uji Reaksi Gram KOH 3\% } \\
\cline { 2 - 6 } Penanaman Bakteri & Sampel Uji 1 & Sampel Uji 2 & Sampel Uji 3 & Sampel Uji 4 & Sampel Uji 5 \\
\hline Sebar & - & + & - & - & + \\
\hline Gores & + & + & + & + & + \\
\hline
\end{tabular}

Keterangan: Tanda plus (+) diberikan apabila terdapat lendir dan tanda minus (-) diberikan apabila tidak terdapat lendir pada saat pengujian
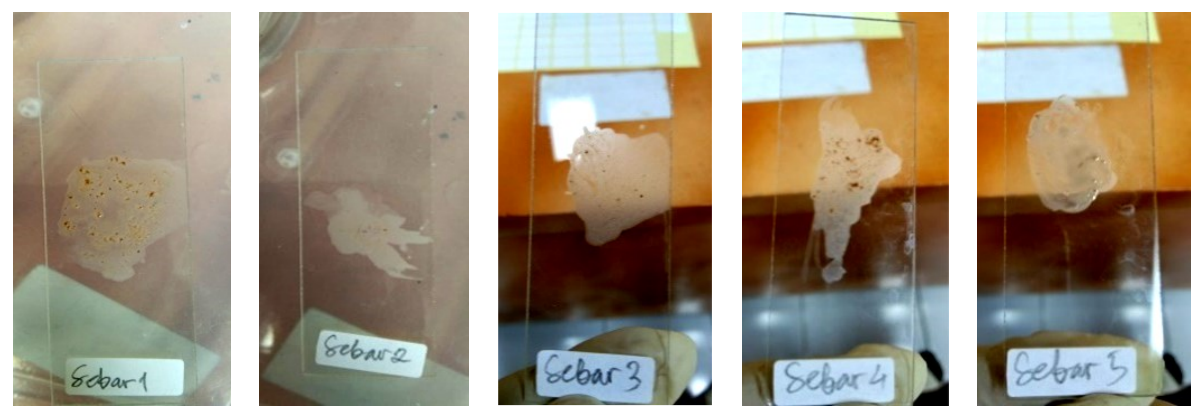

Gambar 1. Pengamatan uji gram bakteri menggunakan $\mathrm{KOH} 3 \%$ dengan metode sebar
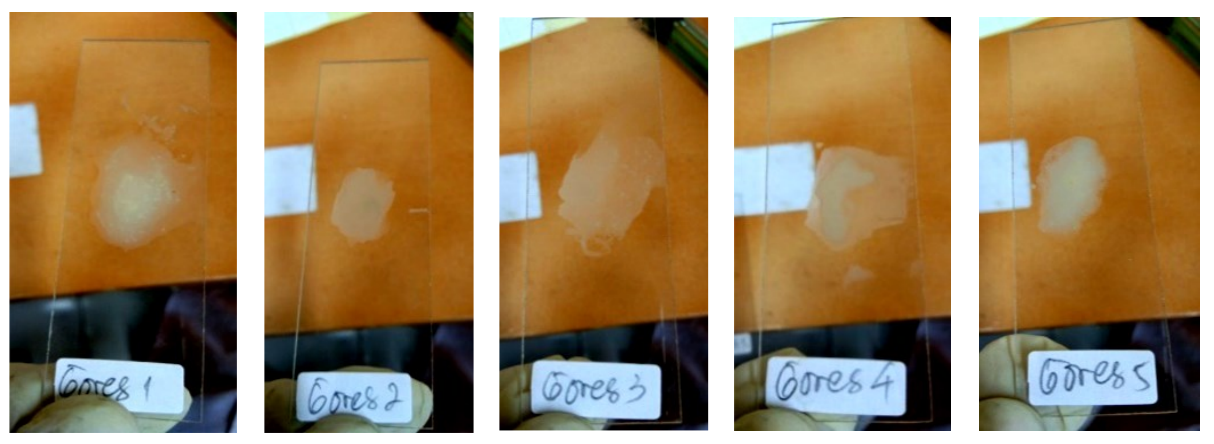

Gambar 2. Pengamatan uji gram bakteri menggunakan $\mathrm{KOH} 3 \%$ dengan metode gores 
Hasil uji reaksi gram (Tabel 1) menunjukkan bahwa PGPR rizosfer bambu berduri pada metode sebar dan metode gores rata-rata menghasilkan lendir saat pengujian reaksi gram dengan menggunakan $\mathrm{KOH} 3 \%$, namun pada pengujian metode gores semuanya memiliki lendir yang berarti seluruhnya merupakan gram negatif dibanding dengan metode sebar yang hanya 2 sampel berlendir. Terbentuknya lendir tersebut dikarenakan pecahnya dinding sel bakteri akibat berada dalam larutan alkali tinggi ketika diberikan $\mathrm{KOH} 3 \%$. Hal tersebut sesuai dengan pernyataan Soekirno (2008), yang menyatakan bahwa reaksi gram dapat di konfirmasi dengan uji kelarutan kalium hidroksida (kori). Dengan mengambil satu ose penuh kultur bakteri yang sedang tumbuh aktif dan dicampurkan dengan setetes larutan $\mathrm{KOH} 3 \%$ di atas kaca objek yang bersih kemudian dilakukan pengadukan hingga diperoleh suspensi yang rata. Jika pada saat ose diangkat dan tampak benang lendir, maka bakteri tersebut adalah gram negatif, namun jika dihasilkan suspensi berair dan tidak tampak adanya benang lendir setelah ose digerakkan berulang maka kultur bakteri itu adalah gram positif. Gram negatif akan membentuk lendir saat uji menggunakan $\mathrm{KOH} 3 \%$ karena pecahnya dinding sel bakteri akibat berada dalam larutan alkali tinggi $(\mathrm{KOH}$ $3 \%$ ). Sedangkan bakteri gram positif tidak membentuk lendir karena dinding sel bakteri gram positif memiliki lapisan peptidoglikan yang tebal. Tes string kalium hidroksida $(\mathrm{KOH})$ digunakan untuk membedakan isolat bakteri. Lingkaran pertumbuhan dari koloni bakteri bercampur dalam suspensi $3 \% \mathrm{KOH}$ berair pada kaca slide. Tes ini dianggap positif jika suspensi seperti gel atau menjadi kental dan keluar ketika loop diangkat, maka isolat adalah gram negatif. Sel-sel Gram-positif tidak membentuk gel kental atau tali keluar (Kurnia et al., 2015). Dalam diagnostik mikrobiologi klinis dan obat klinis, pewarnaan gram membantu identifikasi awal organisme, yang pada gilirannya membantu secara dugaan pengobatan. Tetapi hasil samar muncul dengan beberapa Gram positif dan Gram negatif pada berbagai bakteri (Gregersen, 1978; Dash dan Payyappilli, 2016).

Perbandingan antara persentase kedua metode penanaman bakteri yakni metode sebar dan metode gores (Gambar 3) menunjukkan hasil identifikasi bakteri menggunakan uji gram $\mathrm{KOH} 3 \%$, pada metode sebar persentase memiliki lendir yakni $40 \%$ sedangkan pada metode gores persentase memiliki lendir yakni 100\% sehingga rata-rata bakteri plant growth promoting rhizobacteria dari rizosfer bambu duri memiliki lendir/gram negatif, seperti Enterobactericeae (Escherichia coli, Salmonella, Shigella), Pseudomonas, dll. Terdapat pula bakteri PGPR rizosfer bambu yang tidak memiliki lendir/gram positif, seperti Bacillus, Enterococcus, dll. Hal tersebut sejalan dengan pernyataan Podile and Kishore (2006) yang menyatakan bahwa beberapa genus rhizobacteria yang bersifat sebagai PGPR yaitu Pseudomonas, Enterobacter, Bacillus, Azospirilum, Azotobacter, Burkholderia dan Serratia. Sehingga dapat dinyatakan bahwa bakteri pada PGPR rizosfer bambu berduri aktif dan berperan dalam proses pertumbuhan tanaman.

Tes string $\mathrm{KOH}$ cepat dan dapat membedakan bakteri menjadi Gram positif dan Gram negatif. Dinding sel bakteri Gram positif terdiri dari lapisan peptidoglikan $(90 \%)$, sedangkan bakteri Gram negatif memiliki kandungan lipid yang tinggi pada dinding selnya dalam bentuk liposakarida dan lipoprotein (Aminulloh, 2011; Kurnia et al., 2015). Pada bakteri Gram negatif, dinding sel hanya setebal 1-3 lapis. Pada hadapan kalium hidroksida, dinding sel Gram negatif mudah terganggu, melepaskan bahan kromosom viskid, yang menyebabkan suspensi bakteri menjadi tebal dan berserat. Dinding sel bakteri gram positif tidak terpengaruh oleh 3\% KOH (Madigan et al., 2012; Kurnia et al., 2015).

\section{Persentase Uji Reaksi Gram KOH 3\% Metode Sebar}

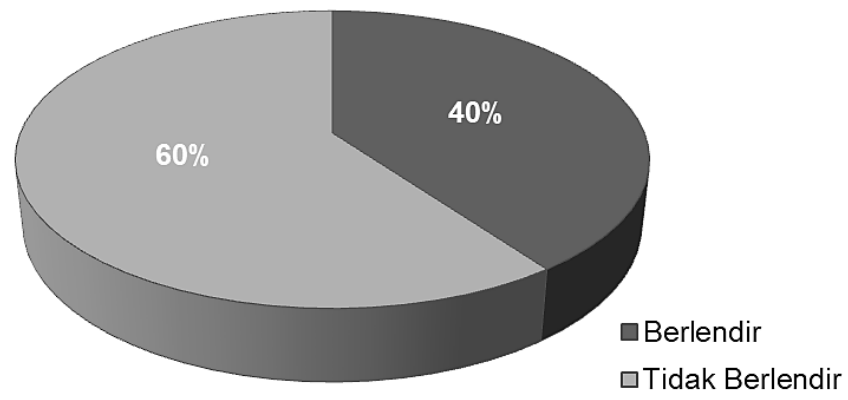

\section{Persentase Uji Reaksi Gram KOH 3\% Metode Gores}

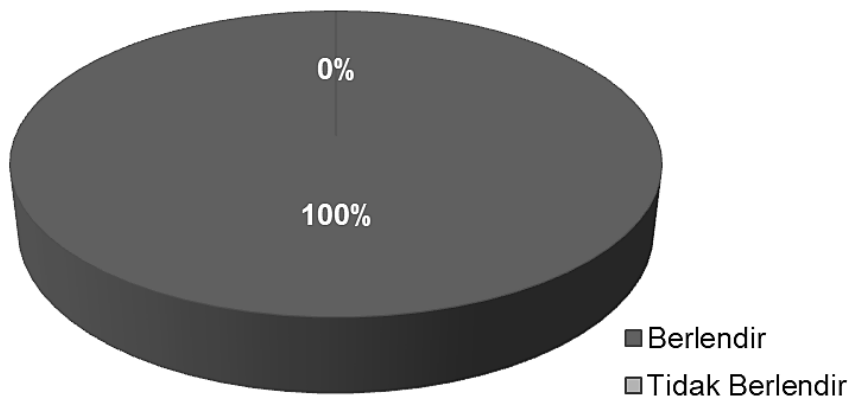

Gambar 3. Grafik perbandingan antara persentase metode sebar dan metode gores hasil uji reaksi gram $\mathrm{KOH} 3 \%$ pada Plant Growth Promoting Rhizobacteria dari rizosfer bambu duri 


\section{KESIMPULAN}

Pada pengujian metode sebar terdapat 2 sampel yang memiliki lendir dengan persentase $40 \%$ sedangkan pada metode gores semua sampel memiliki lendir dengan persentase $100 \%$ sehingga penggunaan metode uji gram $\mathrm{KOH} 3 \%$ berpengaruh optimum dalam mendeteksi mikroorganisme khususnya dalam mengidentifikasi plant growth promoting rhizobacteria.

\section{DAFTAR PUSTAKA}

Aminulloh, F. 2011. Analisis Bahan Organik dan Nitrogen Total pada Sistem Budidaya Ikan pada Skala Laboratorium. Program Keahlian Analisis Kimia Institut Pertanian Bogor, Bogor.

Asniah, Widodo \& Wiyono, S. 2013. Potensi cendawan asal tanah perakaran bambu sebagai endofit dan agen biokontrol penyakit akar gada pada tanaman brokoli. J. Fitopatol Indones. 1 (2): 61-68

Bharti N, Yadav D, Barnawal D, Maji D. \& Kalra A. 2013. Exiguobacterium Oxidotolerans, a Halotolerant Plant Growth Promoting Rhizobacteria, Improves Yield and Content of Secondary Metabolites in Bacopa Monnieri(L.) Pennell Under Primary and Secondary Salt Stress. World J. Microbiol Biotechnol. 29: 379387.

Bhattacharyya PN, Jha DK. 2012. Plant Growth Promoting Rhizobacteria (PGPR): Emergence in Agriculture. World J. Microbiol Biotechnol. 28: 13271350.

Bottini R., Cassan F. \& Piccoli P. 2004. Gibberellin Production by Bacteriaand Its Involvement in Plant Growth Promotion and Yield Increase. Appl Microbiol Biot. 65:497-503

Burd G, Dixon DG, Glick BR. 2000. Plant Growth Promotingbacteria That Decrease Heavy Metal Toxicity in Plants. Can J. Microbiol. 46: 237-245.

Chaiharn M., Chunhaleuchanon S., Kozo A. \& Lumyong S. 2008.Screening of Rhizobacteria for Their Plant Growth Promoting Activities. KMITL Sci Technol J. 8:18-23.

Dash C, Payyappilli RJ. 2016. KOH String and Vancomycin Susceptibility Test as an Alternative Method to Gram Staining. Journal of International Medicine and Dentistry. 3 (2): 88-90

Edwin. 2011. Materi Kuliah Mikrobiologi. Banjarbaru (ID): Universitas Lambung Mangkurat.

Gregersen T. 1978. Rapid Method for Distinction of Gram Negative from Gram Positive Bacteria. European J. Appl Microbiol Biotechnol; 5: 123-127

Jaya CT. \& Subha MP. 2011. A Study of 2 Rapid Tests to Differentiate Gram Positive and Gram Negative Aerobic Bacteria. J. Med Allied Sci; 1(2): 84-85.
Khalid A., Arshad M, Zahir ZA. 2004. Screening Plant Growth Promoting Rhizobacteria for Improving Growth and Yield of Wheat. J Appl Microbiol. 96:473480

Kurnia K., Sadi NH, Jumianto S. 2015. Isolation and Characterization of $\mathrm{Pb}$ Resistant Bacteria from Cilalay Lake, Indonesia. Aceh Int. J. Sci. Technol., 4(3): 83-87

Lin W, Okon Y, Hardy RWF.1983. Enhanced mineral uptake by Zea Mays and Sorghum Bicolorroots Inoculated with Azospirillum-brasi-lense. Appl Environ Microb. 45:1775-1779.

Liu K, McInroy JA, Hu CH. \& Kloepper JW. 2017. Mixtures of Plant Growth Promoting Rhizobacteria Enhance Biological Control of Multiple Plant Diseases and Plant Growth Promotion in the Presence of Pathogens. Plant Dis. 102:67-72

Lugtenberg B, Kamilova F. 2009. Plant Growth Promoting Rhizobacteria. Annu Rev Microbiol. 63: 541-556.

Madigan MT, Martinko JM, Stahl DA. \& Clark DP. 2012. Brock: Biology of Microorganisms. Pearson, San Fransisco

Podile AR, Kishore AK. 2006. Plant Growth Promoting Rhizobacteria. Gnanamanickam SS, editor. PlantAssociated Bacteria. Netherland: Springer.

Rahayu SA, Gumilar MH. 2017. Uji Cemaran Air Minum Masyarakat Sekitar Margahayu Rata Bandung Dengan Identifikasi Bakteri Escherichia coli. Jurnal Sains dan Teknologi Farmasi Indonesia. 4 (2): 50-56

Rahni NM. 2012. Efek Fitohormon PGPR terhadap Pertumbuhan Tanaman Jagung (Zea mays). CEFARS. Jurnal Agribisnis dan Pengembangan Wilayah. 3 (2): 27-35.

Ryu CM, Hu CH, Locy RD, Kloepper JW. 2005. Study of Mechanismsfor Plant Growth Promotion Elicited by Rhizobacteria in Arabidopsisthaliana. Plant Soil. 268:285-292

Saharan BS, Nehra V. 2011. Plant Growth Promoting Rhizobacteria: A Critical Review. Journal of Aston. 21(1): 1-30.

Sharma R, Rjaka RC, Pandey AC. 2010. Evidence of antagonistic interaction between rhizosphere and mycorizhae fungi associated with Dendrocalamus strictus. J. Yeast Fungal Res. 1 (7): 112-117.

Soekirno, 2008. Pedoman Pengelolaan Koleksi dan Identifikasi OPT (khusus untuk pathogen penyakit tanaman) pada Tanaman Holtikultura. Jakarta (ID): Direktorat Perlindungan Tanaman Holtikultura.

Sutrisno. 2008. Budidaya Bambu.Yogyakarta (ID): Balai Pengelolaan Daerah Aliran Sungai Serayu Opak Progo. 
Tsavkelova EA, Klimova SY, Cherdyntseva TA, Netrusov Al. 2006. Microbial Producers of Plant Growth Stimulators and Their Practicaluse: a Review. Appl Biochem Micro. 42:117-126

Tu Z, Chen L, Yu X, Zheng Y. 2013. Effect of bamboo plantation on rhizosphere soil enzyme and microbial activities in coastal ecosystem. J. Food Agric Environ. 11 (03): 2333-2338.

Widjaja EA, Sastrapradja S, Prawiroatmodjo S. \& Soenarko S. 1995. Jenis- Jenis Bambu. Jakarta (ID): Balai Pustaka.
Yang J, Kloepper JW, Ryu CM. 2009. Rhizosphere Bacteria Help Plants Tolerate Abiotic Stress. Trends Plant Sci.14: 1-4.

Zahir ZA, Khalid A, Arshad M. 2004. Screening plant growth promoting rhizobacteria for improving growth and yield of wheat. J. Appl. Microbiol. 96: 473-480.

Zhang $\mathrm{H}$, Kim MS, Krishnamachari V, Payton P, Sun $\mathrm{Y}$, Grimson M, Farag MA, Ryu CM, Allen R, Melo IS. 2007. Rhizobacterial Vola-tile Emissions Regulate Auxin Homeostasis and Cell Expansion in Arabidopsis. Planta. 226:839-851. 